\title{
Voltammetric and Rotating Ring-Disk Studies of the Influence of Anions in the Underpotential Deposition of Zinc on Platinum
}

\author{
Lucia H. Mascaro ${ }^{a}$, M. C. Santos ${ }^{b}$, S. A. S. Machado ${ }^{b}$ and L. A. Avaca ${ }^{b, *}$ \\ ${ }^{a}$ Departamento de Química, Universidade Federal do Paraná, CP 19081, 81531-990 Curitiba - PR, Brazil \\ ${ }^{b}$ Instituto de Química de São Carlos, Universidade de São Paulo, CP 780, 13560-970 São Carlos - SP, Brazil
}

\begin{abstract}
A deposição em regime de subtensão de Zn sobre Pt policristalina foi estudada em três diferentes soluções ácidas para diferentes concentrações de $\mathrm{Zn}^{2+}$. As cargas voltamétricas e a inibição, promovida pelo recobrimento máximo da superfície com $\mathrm{Zn}_{\text {ads }}$, na adsorção e na reação de desprendimento de hidrogênio foram usados para se postular modelos de adsorção. A co-adsorção dos ânions $\mathrm{HSO}_{4}^{-}$, $\mathrm{ClO}_{4}^{-}$e F-, tanto sobre o substrato de $\mathrm{Pt}$ como sobre os ad-átomos, exercem um papel muito importante na natureza da camada adsorvida. Sobre $\mathrm{Pt}$, a carga máxima de redissolução do $\mathrm{Zn}_{\text {ads }}$ encontrada foi aproximadamente $210 \mu \mathrm{C} \mathrm{cm}^{-2}$, exceto para o meio de fluoreto com $\mathrm{Zn}^{2+} 10^{-3} \mathrm{~mol} \mathrm{~L}^{-1}$, onde se encontrou um valor de aproximadamente $350 \mu \mathrm{C} \mathrm{cm}^{-2}$. Uma pequena inibição na reação de desprendimento de hidrogênio foi observada em ácido sulfúrico e perclórico, mas uma intensa inibição foi constatada em meio de ácido fluorídrico. Estes resultados foram associados com a interação dos volumosos oxi-ânions tanto com os ad-átomos como com o substrato. Finalmente, experimentos de coleção com o eletrodo rotatório de disco-anel foram feitos em meio de HF e os resultados confirmaram a carga máxima obtida dos voltamogramas. Os experimentos feitos com o eletrodo rotatório confirmaram que os picos voltamétricos analisados são relacionados com a deposição em subtensão do Zn.
\end{abstract}

The underpotential deposition of $\mathrm{Zn}$ on polycrystalline Pt was studied in three different acid solutions for different $\mathrm{Zn}^{2+}$ concentrations. The voltammetric charges and the inhibition promoted by the maximum coverage of $\mathrm{Zn}_{\text {ads }}$ in the hydrogen adsorption and evolution reactions were used to postulate adsorption models. It was shown that the co-adsorption of anions $\mathrm{HSO}_{4}^{-}, \mathrm{ClO}_{4}^{-}$and $\mathrm{F}^{-}$, either on the substrate or on the ad-atoms, exerts a marked influence in the ad-layer nature. On $\mathrm{Pt}$, the maximum values found for the redissolution charge were around $210 \mu \mathrm{C} \mathrm{cm}^{-2}$, except for $10^{-3} \mathrm{~mol}$ $\mathrm{L}^{-1} \mathrm{Zn}^{2+}$ in fluoride medium where a value of $350 \mu \mathrm{C} \mathrm{cm}^{-2}$ was obtained. A negligible inhibition of the hydrogen evolution reaction was recorded in sulfuric and perchloric acid solutions while a strong inhibition was found for fluoride medium. These results were related to the interaction of the large oxy-anions either with the substrate or the ad-atoms. Collection experiments were performed with the rotating ring-disk electrode system (RRDE) and the results confirmed the large charge value obtained in the HF electrolyte. The experiments performed with the RDDE also demonstrated that the voltammetric peaks analyzed here are associated with UPD Zn.

Keywords: underpotential deposition, zinc, ad-atoms, hydrogen evolution reaction, ad-anions

\section{Introduction}

The electrocrystallization of Ni-Zn alloys on different substrates is one of the most interesting subjects in applied electrochemistry. This is mainly due to the intensive utilization of such deposits in several technological applications like protection against corrosion in automotive industry, ${ }^{1}$ hydrogen production by water electrolysis, ${ }^{2,3}$ energy storage devices ${ }^{4}$ and inhibition of

*e-mail: avaca@iqsc.sc.usp.br hydrogen embrittlement on Ni/Cu Monel K500 alloy ${ }^{5}$ or AISI 4340 steel. ${ }^{6}$ As already observed by Brenner, ${ }^{7}$ the most important characteristic of such system is the anomalous character of $\mathrm{Zn}$ deposition. In the electrochemical deposition of alloys, the term anomalous applies for the reduction of the less noble ion component preferentially than the one predicted only from thermodynamic consideration. ${ }^{8}$ An interesting model proposed by Swathirajan to explain such behavior involves the inhibition of nickel deposition on platinum surfaces by underpotential deposition of zinc. ${ }^{9}$ 
The underpotential deposition of metals has been extensively studied due to the possibility of promoting modifications on the catalyst surface in a specially controlled way. This phenomenon is associated to the interactions between ad-atoms and substrate that make it possible to deposit a metal $\mathrm{M}$ in a potential range more positive than the Nernst potential for the couple $\mathrm{M} / \mathrm{M}^{\mathrm{z}+}$. The main characteristics of these systems have been well described in several papers and reviews. ${ }^{10-12}$

The underpotential deposition of $\mathrm{Zn}$ on different substrates have been recently studied by Aramata et al., mainly on polycrystalline $\mathrm{Pt}, \mathrm{Pd}$ and $\mathrm{Au}^{13,14}$ and on $\mathrm{Pt}$ single crystals. ${ }^{15}$ These authors have investigated the effect of $\mathrm{pH}$ on the anodic shift of the Zn UPD dissolution peak suggesting a twoelectron mechanism with repulsive interaction between adatoms. Nevertheless, a model for $\mathrm{Zn}$ adsorption was not discussed. Dorda et $a l .{ }^{4}$ have analyzed the deposition of $\mathrm{Zn}$ on $\mathrm{Pt}$ from alkaline solutions by cyclic voltammetry, proposing a poisoning of the surface by zinc ad-atoms, which was revealed by the inhibition of the hydrogen adsorption peaks. El-Shafei ${ }^{16}$ investigated the sensitivity of the crystallographic orientation of electrochemically oriented $\mathrm{Pt}$ surfaces for UPD Zn in acid medium using cyclic voltammetry. The UPD Zn was found to be a very convenient process for surface characterization due to the sensitivity of the ad-atom to surface orientation and to the fact that the deposition occurs in a potential range where no changes in the Pt surface structure are observed. ${ }^{16}$

Taguchi and Aramata ${ }^{17}$ have examined the UPD $\mathrm{Zn}$ in pH 4.4 solutions with and without halide anions by cyclic voltammetry. The UPD peak potentials were shifted negatively by anion adsorption that also increases the peak width. These authors assumed a three-step mechanism for the UPD process, namely, (i) desorption of initially adsorbed anions from the substrate, (ii) adsorption of the ad-atom and (iii) re-adsorption of the anions on the UPD metal. This model was used to study the adsorption of $\mathrm{Zn}$ in phosphate medium by cyclic voltammetry, FTIR and electrochemical quartz crystal microbalance (EQCM). ${ }^{18}$ The FTIR measurements pointed to the adsorption of $\mathrm{HPO}_{4}^{2-}$ ions on $\mathrm{Zn}$ through a $\mathrm{Zn}-\mathrm{O}$ bond. The effect of anion adsorption on UPD metal atoms was also discussed by Varga et $a l .{ }^{19}$ for bisulfate on UPD $\mathrm{Cu}$ systems. The electrochemistry of $\mathrm{Zn}^{2+}$ in sulfate medium was also analyzed by Zouari and Lapicque. ${ }^{20}$ The authors had studied the thermodynamics of the $\mathrm{Na}_{2} \mathrm{SO}_{4}-\mathrm{ZnSO}_{4}-\mathrm{H}_{2} \mathrm{O}$ system proposing the existence of $\left(\mathrm{Zn}^{2+}\right)\left(\mathrm{SO}_{4}^{2-}\right)$ ion pairs in the liquid phase. Finally, Horányi and Aramata ${ }^{21,22}$ have studied the adsorption of $\mathrm{Cl}^{-}, \mathrm{HSO}_{4}^{-}$and $\mathrm{H}_{2} \mathrm{PO}_{4}^{-}$on $\mathrm{Pt}$ surfaces induced by the co-adsorption of $\mathrm{Zn}$ ad-atoms. The authors concluded that the specific adsorption of the species induced by $\mathrm{Zn}$ ad-atoms depends on $\mathrm{pH}$ and at a given potential on the concentration of $\mathrm{Zn}^{2+}$ ions.

From the discussion above it is clear that UPD $\mathrm{Zn}$ is not, up to now, sufficiently explored in the literature. Perhaps some difficulties arise in the interpretation of experimental data by the overlap of the $\mathrm{Zn}_{\text {ads }}$ oxidation peaks with desorption of UPD H on Pt or by alloy formation with Au. Moreover, there is a lack of studies indicating the structure of the monolayer with regard to the number of active sites occupied by each ad-atom as well as to the maximum coverage of the surface.

The hydrogen adsorption/evolution reaction is an adequate tool to analyze the blockage of active sites on the $\mathrm{Pt}$ (and even $\mathrm{Au}$ ) surfaces. As each hydrogen atom needs one site to adsorb (and evolve $\mathrm{H}_{2}$, in the sequence), any decrease in the hydrogen adsorption charge or inhibition of hydrogen evolution means a blockage of the surface by a different foreign ad-atom. This particular behavior is proposed to be used here in order to postulate adsorption models for UPD Zn.

Therefore, the objective of this work is to study the underpotential deposition of $\mathrm{Zn}$ on polycrystalline platinum surfaces in $0.5 \mathrm{~mol} \mathrm{~L}^{-1} \mathrm{H}_{2} \mathrm{SO}_{4}, \mathrm{HClO}_{4}$ and $\mathrm{HF}$ solutions The electrochemical techniques to be used are cyclic voltammetry and rotating ring-disk electrodes and the UPD $\mathrm{Zn}$ response will be analyzed in relation to the behavior of the hydrogen adsorption/evolution on platinum and gold, aiming to explore some aspects of this system that still remain under discussion.

\section{Experimental}

A three-compartment electrochemical cell was constructed in Pyrex glass and provided with a Luggin capillary for the reference electrode. The working electrode for the voltammetric experiments was a platinum disc with $0.199 \mathrm{~cm}^{2}$ electrochemical area, as evaluated by the charge associated with the desorption of one monolayer of Hads. ${ }^{23,24}$ For the hydrodynamic experiments a Pt-Pt configuration with a $0.001 \mathrm{~cm}^{2} \mathrm{Pt}$ ring and $0.160 \mathrm{~cm}^{2}$ Pt disk was used. The collection coefficient was determined with the $\mathrm{Fe}^{2+}$ / $\mathrm{Fe}^{3+}$ couple as 0.195 . A $5 \mathrm{~cm}^{2}$ platinum foil was used as the auxiliary electrode while the reversible hydrogen electrode (RHE) was the reference system.

The acid solutions used in this work were prepared with $\mathrm{H}_{2} \mathrm{SO}_{4}$ (Merck, Suprapur), $\mathrm{HClO}_{4}$ (Merck, P.A.) or $\mathrm{HF}$ (Merck, P.A.), ZnO (Merck, P. A.) and water purified in a Milli-Q system (Millipore Inc.) and were deaerated by bubbling $\mathrm{N}_{2}$ (SS White Martins).

Cyclic voltammetry was carried out using an EG\&G PARC model 273 potentiostat/galvanostat linked to an 
IBM compatible PC 486 microcomputer controlled by the software M270 (EG\&G PARC) while for the rotating ringdisk experiments a model 366A EG\&G PARC bipotentiostat, a rotating system model 636 EG\&G PARC and a model 7046B Hewlett Packard recorder were used.

\section{Results and Discussion}

\section{Cyclic voltammetric studies}

The voltammetric behavior of $\mathrm{Pt}$ at $0.2 \mathrm{~V} \mathrm{~s}^{-1}$ in the three different media under investigation is presented in Figure 1. The dotted-line curves represent the steady-state voltammetric response of the surface in the blank solutions. On the sequence, $\mathrm{ZnO}$ was added to the blank solutions, the electrode was held for $300 \mathrm{~s}$ at the initial potential $(0.05 \mathrm{~V})$ and the first voltammetric cycle recorded afterward. To achieve maximum surface coverage with $\mathrm{Zn}_{\text {ads }}$ the $\mathrm{Zn}^{2+}$ concentration was varied from $10^{-5}$ to $10^{-3} \mathrm{~mol} \mathrm{~L}^{-1}$ and further up. It was found that $10^{-3} \mathrm{~mol} \mathrm{~L}^{-1} \mathrm{Zn}^{2+}$ in the solution was sufficient for that purpose in three electrolytes under investigation, all other conditions maintained constant. This is shown by the full-line voltammograms in Figure 1.

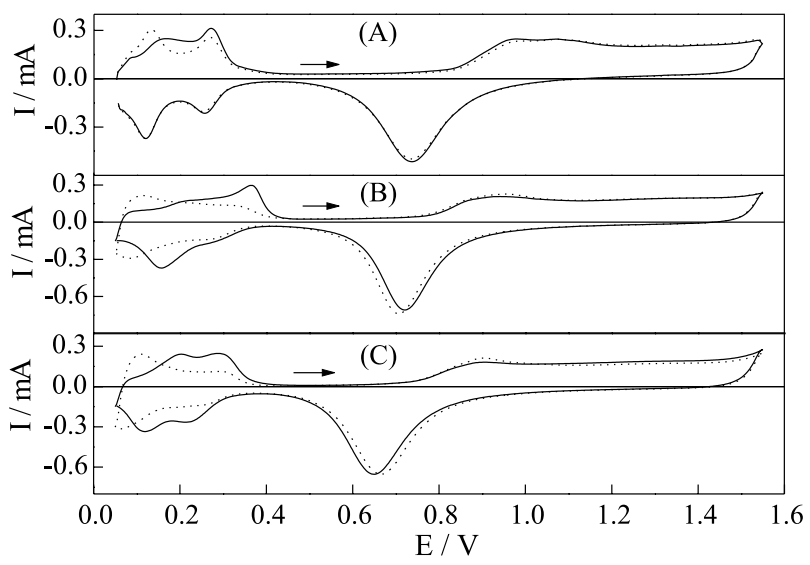

Figure 1. Steady-state profiles (dotted lines) for Pt in $0.5 \mathrm{~mol} \mathrm{~L}^{-1}$ $\mathrm{H}_{2} \mathrm{SO}_{4}$ (A), $\mathrm{HClO}_{4}$ (B) and $\mathrm{HF}$ (C) and first-cycle voltammograms at $0.2 \mathrm{~V} \mathrm{~s}^{-1}$ after the addition of $1 \times 10^{-3} \mathrm{~mol} \mathrm{~L}^{-1} \mathrm{ZnO}$ (full lines). Prior to potential scanning, a delay time of $300 \mathrm{~s}$ at $0.05 \mathrm{~V}$ was imposed to the electrode in order to reach a maximum coverage with $\mathrm{Zn}_{\text {ads }}$.

The two anodic peaks observed in Figure 1A, 1B and $1 \mathrm{C}$ in the potential range between 0.05 and $0.4 \mathrm{~V}$ could be either associated to the dissolution of $\mathrm{Zn}_{\text {ads }}$ deposited for $300 \mathrm{~s}$ at $0.05 \mathrm{~V}$ or to the oxidation of $\mathrm{H}$-atoms adsorbed on the electrode surface. It is very difficult to distinguish these oxidation processes by cyclic voltammetry. However, the use of a rotating ring-disk electrode system will be useful to clarify this point (see later).
Meanwhile, the dissolution responses are clearly affected by the anions of the electrolyte as their shape and peak potentials are quite different in the three cases. Thus, for sulfuric acid solutions (Figure 1A) a well-defined peak is observed at around $0.27 \mathrm{~V}$ and this can be associated with the strongly adsorbed $\mathrm{Zn}$ while the shoulder appearing at approximately $0.16 \mathrm{~V}$ is due to the weakly adsorbed $\mathrm{Zn}$, as previously reported. ${ }^{13}$ The maximum dissolution charge density obtained here after deposition at $0.05 \mathrm{~V}$ during $300 \mathrm{~s}$ was $225 \mu \mathrm{C} \mathrm{cm}^{-2}$. By comparison with the charge density value associated to the desorption of a complete hydrogen monolayer $\left(210 \mu \mathrm{C} \mathrm{cm}^{-2}\right)$, a well-known one-electron transfer reaction where each $\mathrm{H}$ ad-atom is bonded to one active site on the platinum surface ${ }^{23,25}$ it can be proposed that the present case corresponds to the occupancy of only one-half of a monolayer with $\mathrm{Zn}_{\text {ads }}$ in a two-electron transfer reaction. This is because each $\mathrm{Zn}$ ad-atom is assumed to deposit onto only one Pt active site, in accordance with their very close atomic radii values (1.39 $\AA$ for $\mathrm{Pt}$ and $1.38 \AA$ for $\mathrm{Zn}^{26}$ ).

To investigate the influence of bisulfate adsorption in the measured partial coverage with $\mathrm{Zn}_{\text {ads }}$ described above, the experiments performed in $0.5 \mathrm{~mol} \mathrm{~L}^{-1} \mathrm{HClO}_{4}$ under the same conditions (Figure 1B) were comparatively analyzed. The most significant difference in relation to the profile in Figure $1 \mathrm{~A}$ is the shift to $0.36 \mathrm{~V}$ of the peak potential for the strongly adsorbed $\mathrm{Zn}$ and the ill-defined shoulder at $0.23 \mathrm{~V}$. For the maximum desorption charge density the value was $230 \mu \mathrm{C} \mathrm{cm}^{-2}$ in this case. These observations suggest that the adsorption of bisulfate ions on the Pt surface might not be the main reason for low value measured for $\mathrm{Zn}_{\text {ads }}$ coverage since perchlorate adsorption on $\mathrm{Pt}$ is much weaker than that of bisulfate ${ }^{27}$ and, in both media, the $\mathrm{Zn}_{\text {ads }}$ desorption charge densities have almost identical values.

The next step towards a better understanding of the $\mathrm{Zn}$ UPD process was to analyze the experiments in $0.5 \mathrm{~mol} \mathrm{~L}^{-1}$ HF. Here, the electrolyte was selected due to the low adsorbability of fluoride ions on Pt (similar to that of perchlorate) together with the fact that $\mathrm{F}^{-}$is not an oxyanion. The proposition here is that oxy-anions could adsorb on top of $\mathrm{Zn}_{\text {ads }}$, as previously reported ${ }^{17}$ and block the neighbor site of the substrate by means of a hydrogen bond. The corresponding voltammogram (Figure 1C) shows two well-defined oxidation peaks at approximately 0.29 and $0.20 \mathrm{~V}$, respectively, in an overall behavior similar to that observed for sulfuric acid. On the other hand, the maximum charge density measured for the desorption of $\mathrm{Zn}_{\text {ads }}$ was $360 \mu \mathrm{C} \mathrm{cm}^{-2}$, a value significantly higher than those for perchlorate and for sulfate ions. Only small differences are observed if the $\mathrm{Zn}^{2+}$ concentration is diminished down to $10^{-5} \mathrm{~mol} \mathrm{~L}^{-1}$. Such charge density value implies in a $86 \%$ maximum coverage with $\mathrm{Zn}$ ad-atoms. 
To provide more evidence for the effect of the anions on the Zn UPD on Pt, the influence of the adsorbed metal monolayer in the hydrogen adsorption/evolution reactions was analyzed in the three electrolytes. Figure 2 shows the voltammetric profiles (first cycle) obtained after extending the initial potential value to $-0.05 \mathrm{~V}$ to detect the response of the hydrogen evolution reaction (her). The experimental conditions and the lines representation are the same of those of Figure 1 but for HF (Figure 2C) the response for $10^{-4} \mathrm{~mol} \mathrm{~L}^{-1} \mathrm{Zn}^{2+}$ was also included.

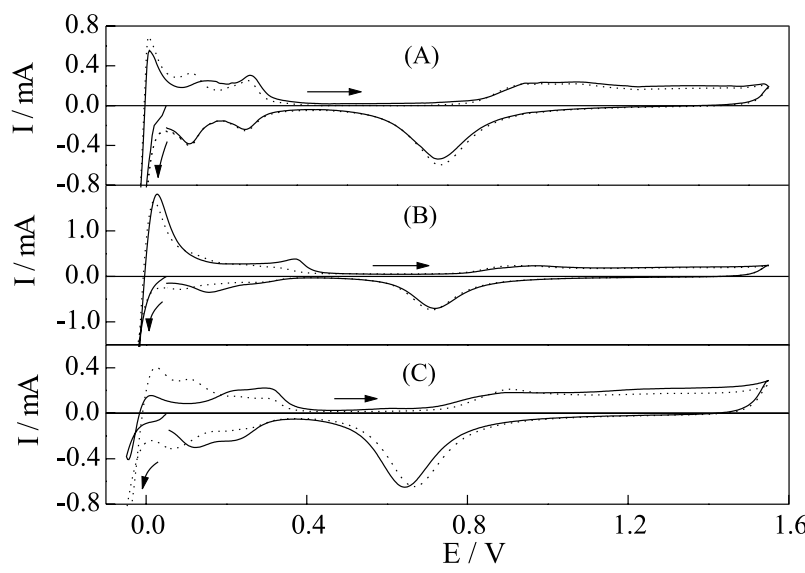

Figure 2. First-cycle voltammograms for $\mathrm{Pt}$ in $0.5 \mathrm{~mol} \mathrm{~L}^{-1} \mathrm{H}_{2} \mathrm{SO}_{4}$ (A), $\mathrm{HClO}_{4}$ (B) and $\mathrm{HF}$ (C) at $0.2 \mathrm{~V} \mathrm{~s}^{-1}$ and after the addition of: $1 \times 10^{-5} \mathrm{~mol} \mathrm{~L}^{-1}$ (dotted lines) and $1 \times 10^{-3} \mathrm{~mol} \mathrm{~L}^{-1}$ (full lines) $\mathrm{ZnO}$. The cathodic potential incursion was extended up to $-0.05 \mathrm{~V}$, in the hydrogen evolution reaction region.

The results in Figure 2 show that only the Zn UPD monolayer obtained with $10^{-3} \mathrm{~mol} \mathrm{~L}^{-1} \mathrm{Zn}^{2+}$ in $0.5 \mathrm{~mol} \mathrm{~L}^{-1}$ $\mathrm{HF}$ is able to inhibit the her, in accordance with the surface coverage by $\mathrm{Zn}_{\text {ads }}$ measured under those conditions. The occupancy of only one-half of a monolayer with $\mathrm{Zn}_{\text {ads }}$ in sulfate and perchlorate solutions, together with the lack of a considerable inhibition of the her, suggests that the oxyanions must be responsible for the low surface coverage with $\mathrm{Zn}$, allowing the her to proceed on the free active sites. A possible model for the representation of this effect of the oxy-anions has been given by Taguchi and Aramata ${ }^{17}$ and can be represented by:

$$
\begin{aligned}
& \mathrm{HSO}_{4}^{-} / \mathrm{Pt} \rightarrow \mathrm{HSO}_{4}^{-} \\
& \mathrm{Zn}^{2+}+2 e^{-} \rightarrow \mathrm{Zn}_{\text {Ads }}^{0} / \mathrm{Pt} \\
& \mathrm{HSO}_{4}^{-} \rightarrow \mathrm{HSO}_{4}^{-} / \mathrm{Zn}_{\mathrm{Ads}}^{0}
\end{aligned}
$$

with the oxy-anions adsorbed on $\mathrm{Zn}_{\text {ads }}$ through one of the oxygen atoms.
At the same time, the $\mathrm{HSO}_{4}^{-}$ions already adsorbed on the $\mathrm{Zn}$ ad-atom could be bonded to the neighbor active site of the platinum surface. This will result from the interaction between one of the $\mathrm{O}$ atoms in the bisulfate ion and the Pt substrate thus blocking the whole surface for the hydrogen UPD. At high cathodic potentials, the weak anion adsorption on the substrate would be eliminated allowing the her to occur. This interpretation could also be valid for the $\mathrm{ClO}_{4}^{-}$ions and will account for the charge density of $210 \mu \mathrm{C} \mathrm{cm}^{-2}$ measured for the half of a monolayer of $\mathrm{Zn}$ arranged in such a way that each ad-atom occupies one active site on the surface and blocks the neighbor site.

\section{Rotating ring-disk studies}

In this work, the rotating ring-disk experiments, performed at $2000 \mathrm{rpm}$, consisted in polarizing the ring electrode at a sufficiently negative potential, in this case at $-0.75 \mathrm{~V}$, in order to allow the massive deposition of $\mathrm{Zn}$ to occur. In this situation, the constant current flowing through the ring surface is due to the Nernstian process $\mathrm{Zn}^{2+} / \mathrm{Zn}$, depending only in the rotating rate and in the $\mathrm{Zn}^{2+}$ concentration, without any influence of the substrate. ${ }^{28,29}$ The next step, with the ring under constant polarization, is related to the deposition of a full $\mathrm{Zn}$ monolayer on the disk electrode surface. This was achieved by polarizing the disk electrode at sufficient negative potentials during different deposition times. After each deposition time, the electrode was submitted to a positive potential sweep up to $1.40 \mathrm{~V}$, at $0.2 \mathrm{~V} \mathrm{~s}^{-1}$, aiming to reach the total dissolution of $\mathrm{Zn}_{\mathrm{ads}}$. This procedure promotes an increase in the $\mathrm{Zn}^{2+}$ concentration in the diffusion layer, during the dissolution of the monolayer. This extra amount of zinc was collected by the ring electrode originating a variation in the constant Nernstian ring current, which is associated with the charge of dissolution of the $\mathrm{Zn}$ monolayer on the disk.

The experiments with the rotating ring-disk system for UPD $\mathrm{Zn}$ in $0.5 \mathrm{~mol} \mathrm{~L}^{-1} \mathrm{H}_{2} \mathrm{SO}_{4}$ or $\mathrm{HClO}_{4}$ solutions on $\mathrm{Pt}$ electrodes, as defined above, did not succeed, probably due to the strong interference of the hydrogen evolution reaction on the ring electrode. In this way, only the experiments with $0.5 \mathrm{~mol} \mathrm{~L}^{-1} \mathrm{HF}$ yielded results to be analyzed. This can be associated to the higher surface coverage with $\mathrm{Zn}_{\text {ads }}$ obtainable in this electrolyte, which can minimize the hydrogen evolution on the disk or on the ring electrodes.

The results obtained for the rotating ring-disk system in $0.5 \mathrm{~mol} \mathrm{~L}^{-1} \mathrm{HF}+10^{-3} \mathrm{~mol} \mathrm{~L}^{-1} \mathrm{ZnO}$ solution and in the same conditions given above, are presented in Figure 3. It can be noted the sensibility of the ring electrode to collect 
the excess of $\mathrm{Zn}^{2+}$ from the dissolution of $\mathrm{Zn}$ monolayer occurred in the disk electrode. Here, the monolayer of $\mathrm{Zn}$ was obtained by keeping the disk potential at $-0.05 \mathrm{~V}$ by $300 \mathrm{~s}$. Further increasing in deposition time does not promote any effect in the dissolution profile. The results obtained in the disk are in close agreement with that obtained with the stationary electrode. The voltammetric charge due to the dissolution of $\mathrm{Zn}$ monolayer was calculated from the disk response as $360 \mu \mathrm{C} \mathrm{cm}^{-2}$. On the other hand, the current variation in the ring electrode was also transformed in charge and, using the collecting factor and the disk electrochemical area, transposed to the value of the dissolution charge on the disk. By these procedures, a charge of $350 \mu \mathrm{C} \mathrm{cm}^{-2}$ was calculated for the disk process, also in agreement with the previous values.

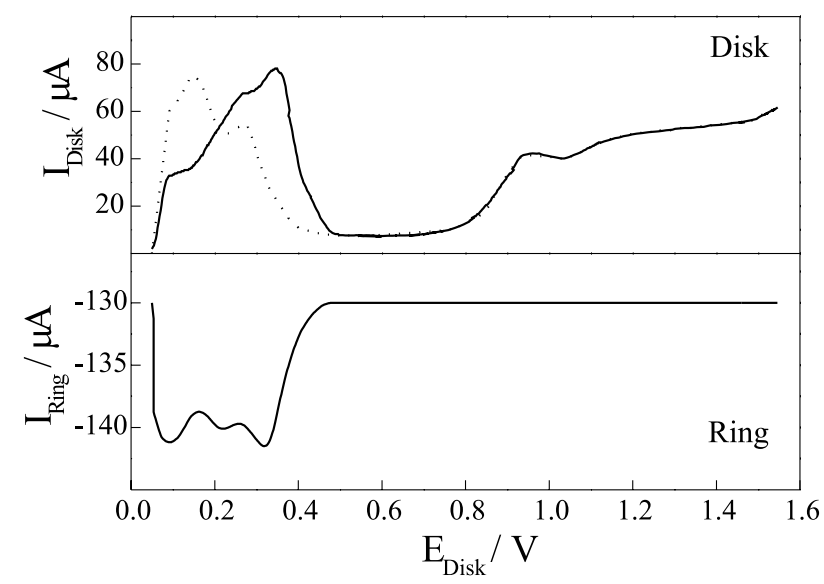

Figure 3. Linear sweep voltammograms for the disk electrode in the $\mathrm{Pt} / \mathrm{Pt}$ rotating ring-disk system and the corresponding ring response in $0.5 \mathrm{~mol} \mathrm{~L}^{-1} \mathrm{HF}$ (dotted line) and after the addition of $10^{-3} \mathrm{~mol} \mathrm{~L}^{-1}$ $\mathrm{ZnO}$ (full line) to the electrolyte. Scan rate of $0.1 \mathrm{~V} \mathrm{~s}^{-1}, \mathrm{E}_{\text {dep }}=300 \mathrm{~s}$, $\mathrm{E}_{\text {ring }}=-0.05 \mathrm{~V}, \omega=2.000 \mathrm{rpm}$ and collection factor $=0.195$.

\section{Conclusions}

The results presented above can be interpreted as an example of the strong interactions that exist in the early stage of metals electrodeposition between ad-atoms, anions and substrates. The adsorption and evolution of hydrogen were used as adequate test reactions to point out the number of active sites covered by the UPD $\mathrm{Zn}$.

As the atomic radius of $\mathrm{Zn}$ is slightly smaller than that of $\mathrm{Pt}$, it should be expected that at maximum coverage each active site on the electrode surface would be occupied by one ad-atom following a two-electron transfer. However, the interactions mentioned above led the depositions to follow quite different pathways.

In sulfuric and perchloric acid media, the total charge obtained corresponds only to one-half of a monolayer and this justifies the partial inhibition of the hydrogen evolution reaction. In hydrofluoric acid medium, the much higher coverage obtained (about 86\%) is responsible for the intense inhibition of the her.

The origin of such different behavior can be related to the participation of the $\mathrm{ClO}_{4}^{-}$and $\mathrm{HSO}_{4}^{-}$molecules in the adsorption model that accounts for the blocking of one extra platinum site per $\mathrm{Zn}$ ad-atom. This was confirmed by the higher coverage found in $\mathrm{F}^{-}$medium.

\section{Acknowledgments}

Thanks are due to CNPq and FAPESP (proc. No 97/ 2978-3) for the financial support.

\section{References}

1. Miura N.; Saito T.; Kanamura T.; Shindo Y.; Kitazawa Y.; Trans. Iron Steel Inst. Jpn. 1983, 23, 913.

2. Chen L.; Lasia A.; J. Electrochem. Soc. 1991, 138, 3321.

3. Giz, M.J. de; Machado, S.A.S.; Avaca; L.A.; Gonzalez; E.R.; J. Appl. Electrochem. 1992, 22, 973.

4. Dorda, A.A.; McLarnon, F.R.; Cairns, E.J.; J. Electroanal. Chem. 1994, 364, 71.

5. Zheng, G.; Popov, B.N.; White, R.E.; J. Electrochem. Soc. 1994, 141, 1220.

6. Zheng, G.; Popov, B.N.; White, R.E.; J. Electrochem. Soc. 1993, 140, 3153.

7. Brenner, A.; Electrodeposition of Alloys, Academic Press: New York, 1963.

8. Nicol, M.J.; Philip, H.I.; J. Electroanal. Chem. 1976, 70, 233.

9. Swathirajan, S.; J. Electroanal. Chem. 1987, 221, 211.

10. Kolb, D.M.; Adv. Electrochem. Electrochem. Eng. 1978, 11, 125.

11. Adzic, R.R.; Adv. Electrochem. Electrochem. Eng. 1984, 13, 159.

12. Szabó, S.; Int. Phys. Chem. 1991, 10, 207.

13. Aramata, A.; Quaiyyum; Md.A.; Balais, W.A.; Atoguchi, T.; Enyo, M.; J. Electroanal. Chem. 1992, 338, 367.

14. Quaiyyum, Md.A.; Aramata, A.; Moniwa, S.; Taguchi, S.; Enyo, M.; J. Electroanal. Chem. 1994, 373, 61.

15. Taguchi S.; Aramata A.; Quaiyyum, Md.A.; Enyo, M.; J. Electroanal. Chem. 1994, 374, 275.

16. El-Shafei, A.A.; J. Electroanal. Chem. 1995, 380, 269.

17. Taguchi, S.; Aramata, A.; J. Electroanal. Chem. 1995, 396, 131.

18. Aramata, A.; Terui, S.; Taguchi, S.; Kawaguchi, T.; Shimazu, K.; Electrochim. Acta 1996, 41, 761.

19. Varga, K.; Zelenay, P.; Wieckowski, A.; J. Electroanal. Chem. 1992, 330, 453. 
20. Zouari, I.; Lapicque, F.; Electrochim. Acta 1992, 37, 439.

21. Horányi, G.; Aramata, A.; J. Electroanal. Chem. 1997, 434, 201.

22. Horányi, G.; Aramata, A.; J. Electroanal. Chem. 1997, 437, 259.

23. Woods, R. In Electroanalytical Chemistry; Bard, A.J. ed., Marcel Dekker: New York, 1976.

24. Angerstein-Kozlowska, H.; Conway, B.E.; Barnett, B.; Mozota, J.; J. Electroanal. Chem. 1979, 100, 417.

25. Woods, R.; J. Electroanal. Chem. 1974, 49, 217.

26. Furuya, N.; Motoo, S.; J. Electroanal. Chem. 1979, 98, 189.
27. Angerstein-Kozlowska, H.; Conway, B. E.; Hamelin, A.; Stoicoviciu, L.; Electrochim. Acta 1986, 31, 1051.

28. Santos, M. C.; Mascaro, L. H.; Machado, S. A. S.; Avaca, L. A.; J. Chem. Soc., Faraday Trans. 1997, 93, 3999.

29. Santos, M. C.; Mascaro, L. H.; Machado, S. A. S.; Electrochim. Acta 1998, 43, 2263.

Received: January 16, 2002

Published on the web: August 1, 2002

FAPESP helped in meeting the publication costs of this article. 